\title{
The Research of Renewable Energy Utilization In Beijing's New Airport
}

\author{
Junku Xu ${ }^{1,2, ~ a, ~ L u b i n g ~ W a n g ~}{ }^{3, b}$ and Aimin Geng ${ }^{3, c}$ \\ ${ }^{1}$ China Airport Construction Group Corporation,Beijing,100101,China \\ ${ }^{2}$ Beijing Super-Creative Technology Co.LTD,Beijing,100621, China \\ ${ }^{3}$ Beijing's New Airport Construction Headquarters(BNAH), 102602, China

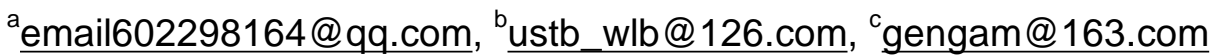

Keywords: The Solar Energy;Geothermal Energy;Renewable Energy Utilization.

Abstract. This paper analyze and study the condition of renewable energy in Beijing's new airport area, and puts forward the use solutions and suggestions of renewable energy in the new airport area.

\section{Introduction}

Beijing's new airport is committed to become a world-class level of efficient, high-quality, green new goalkeeper, establish "green airport bar" and "sustainable, low carbon development paradigm" airport. In order to achieve this goal, new equipment, new technology and renewable energy for energy conservation and environmental protection must be used.It is the important way to realize green airport by effectively using renewable energy.There are many different kinds of renewable energy, which is mainly suitable for Beijing new airport are solar and geothermal resources.

\section{The renewable resource conditions in the new airport area}

\section{Solar energy resources}

Solar energy resources in Beijing's new airport area is high rich, and the average annual total radiation is up to $5600 \mathrm{MJ} / \mathrm{m}^{2}$. According to China's solar energy resources division standard, the region belongs to the "rich"and suitable for use.

Suppose that the area has $27 \mathrm{~km}^{2}$, there is sunshine energy more than 40 billion KWh/year in total. In theory, suppose that the solar energy conversion rate is $10 \%$ and the area laying solar power systems occupies $1 \%\left(270000 \mathrm{~m}^{2}\right)$ of the total area , 40 million KWh of power consumption can be provided in a year.

In addition, solar-thermal use is also very suitable.

\section{Geothermal resources}

\section{Shallow geothermal}

The new airport is located in southern Daxing district in Beijing, and in the downstream of the river alluvial fans. According to professional survey and evaluation, the new airport regional is belongs to ability good area for strata heat exchange, and it has good drillability. Therefore, if shallow geothermal energy is needed, buried pipe ground source heat pump should be used.

Suppose that heating load estimation is $100 \mathrm{w} / \mathrm{m}^{2}$, in theory, the way of adopting ground source heat pump can give heating area for several millions of $\mathrm{m}^{2}$.

The deep geothermal resource

There are Lixian fault zone and Anding fault zone surrounding the new airport . Lixian fault zone is the main fracture structure., and Anding fault zone is the secondary fracture of Lixian fault zone.

According to a rough estimation of the survey of the professional company, the project area geothermal resource is about $6.86 \times 10^{15} \mathrm{~kJ}$ ( the average thickness of $2000 \mathrm{~m}$, thermal storage heat reservoir average temperature $60{ }^{\circ} \mathrm{C}$ ). If $1 \%$ of heat energy can be mined, in combination with heat pump of cascade utilization of heating energy, about 2 million $\mathrm{m}^{2}$ can be heated. 


\section{The use planning of renewable energy}

Based on the analysis of the resource conditions, considering the reality such as technology, capital and time limit for a project under the premise, we make the following program planning of renewable energy for Beijing's new airport.

\section{The use of solar heat/solar-thermal}

Construction of solar hot water system. In Buildings for passengers for the night, dormitory and office building, all adopt solar domestic hot water supply. Available solar device is installed in the building roof; Installation direction of roof in the south is advisable to $15^{\circ}$ angle. Set up solar panels of about $64,500 \mathrm{~m}^{2}$, it can generate more than 34 million $\mathrm{kWh}$ for heat in a year.

\section{The use of solar photovoltaic (pv)}

Appropriate using photovoltaic (pv) power generation. According to the functions and features of the airport, can be considered to install solar photovoltaic panels in transfer center, parking building, parking lot and on the roof of the cargo area; Installation direction of roof in the south is advisable to $15^{\circ}$ angle; Install power $8.4 \mathrm{MW}$, it can generate 8.4 million $\mathrm{kWh}$ energy in a year.

\section{The use of shallow geothermal resources}

Use of shallow geothermal energy for heating and cooling for about $80,000 \mathrm{~m}^{2}$, Such as executive terminal, the airport shift dormitory, canteen and other low density area We can extract heating energy every year is about 11 million $\mathrm{kWh}$, refrigeration energy about 19 million $\mathrm{kWh}$.

\section{The use of deep geothermal resources}

Adopt deep geothermal resources for heating in public security, armed police room and buildings passengers for the night (heating area of about $100,000 \mathrm{~m}^{2}$ ), we can extract 14 million $\mathrm{kWh}$ in every year.

If the above plan of renewable energy project can be implemented, we can use for at least 86.4 million $\mathrm{kWh}$. According to the Beijing airport energy-saving assessment report, the current ratio of renewable energy can arrive to $10 \%$.

\section{Benefit estimation and analysis}

\section{Economic benefits}

Usually, the life of a solar pv system is 25 years, solar-thermal systems for 15 years, geothermal system can run 20 to 30 years.

Without the present state and local subsidies, solar photovoltaic power generation system of investment and economic benefit is basic quite or slightly owe. Solar-thermal systems and shallow geothermal energy utilization can get money (disinvestment) within five years .The deep geothermal systems need recoup for 8 to 9 years.

It is obvious that the economic benefit is great in the system life period: At least 10 years, a year has free 78 million $\mathrm{kWh}$, electricity cost saving at least 48 million yuans (price:0.6 0.7 $\mathrm{Y} / \mathrm{KWh}$ ).

If receiving the current subsidy for the government, to get money needs less time. There are more economic benefits.

Also, many kinds of emissions are reduced , such as $\mathrm{CO}_{2}, \mathrm{SO}_{2}$, smoke and dust etc.

\section{Environmental benefits}

If use of renewable energy is in accordance with the foregoing scale, the solar photovoltaic system will abate $\mathrm{CO}_{2} 0.837$ tons a year, and solar-thermal systems abate $\mathrm{CO}_{2} 3.38$ tons a year and the shallow geothermal system abate $\mathrm{CO}_{2} 1.8$ tons a year, the deep geothermal system abate $\mathrm{CO}_{2} 2.82$ tons every year.

The calculation results show that the solar water heater and electric water heater, per $2 \mathrm{~m}^{2}$ installation of solar water heater (assuming that auxiliary heating equipment for the electric heating mode, using

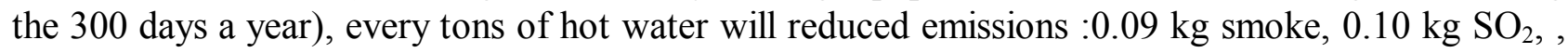
$10.9 \mathrm{~kg} \mathrm{CO} 2$ comparable to electric water heater.If 1 ton hot water is gained, the consumption of the 
solar energy water heater can power saving $9.27 \mathrm{kWh}$ electricity comparing with the consumption of electric water heater power.

Accordingly the above estimation, per $2 \mathrm{~m}^{2}$ installation of solar water heater can reduce : $32.2 \mathrm{~kg}$ smoke and dust emissions, $35.8 \mathrm{~kg} \mathrm{SO}_{2}, 3902 \mathrm{~kg} \mathrm{CO}_{2}$ in its life cycle (15 years), and save 1,257.8 $\mathrm{kg}$ TCE.Only this plan of solar hot water system, will reduce emissions of 1,038 tons of soot, 1,154 tons of $\mathrm{SO}_{2}$ and 125,800 tons of $\mathrm{CO}_{2}$, save 40,564 tons TCE in its life cycle (15 years).

\section{Conclusions and recommendations}

\section{Conclusions}

To sum up, we may draw the following conclusion:

There is more abundant and renewable energy in Beijing's new airport area to be used for a long time.we should make full development and utilization of renewable energy for building cooling and heat sources, promote energy grade, and realize clean and sustainable development.

The use of renewable energy In Beijing new airport, in addition to completing the target of renewable energy utility, will also be able to implement the national policy, social responsibility, at the same time also is one of the great innovation for airport energy solutions.

\section{Recommendations}

1.The best business model is given priority to with professional company, Set up a joint venture with the relevants, and the professional company as the investment main body, the joint venture will be entirely responsible for investment, construction and operation of new energy system.In this way, it can avoid the risk of system operation to the greatest extent.

2.The ground source heat pump system is used to the monomer buildings for heating and cooling.In line with the energy-saving land-saving green airport construction goal, and considering the ground source heat pump hot and cold load balancing, the ground source heat pump construction area shoulds not be too big.

3.The further detailed investigation must be completed combining with the characteristics of the new airport, before the design and construction of the geothermal system in the airport. Then, the solution should be put forward with giving full consideration to the problems and happens in the operation process.

\section{Acknowledgements}

This work was financially supported by the National Science and Technology Support Plan_" Green airport construction key technology research and demonstration" (Topic 1:2014BAJ04B01). Thank you, Ms. Zhao Ying, the outstanding engineer of Beijing's new airport construction headquarters, and her help.

\section{References}

[1] The hydrogeologic and engineering geological brigade of Beijing: Beijing plain of shallow geothermal energy under special geological survey report (Beijing municipal bureau of geological exploration,China 2008).

[2] China Wuzhou engineering design group co., LTD: Beijing's new airport construction projectsEnergy-saving assessment report (Xiaoli Zhai etc., China 2013). 